私れ不乑調発会まう公本本 不。公主查現階势の平研研 公社平義夏 平会感 1 力 一面値にの 感的少機夕三公にがと拈目 は不発会を和平市しけ的 達会現主角㕕価人る、るは

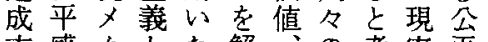
志感力とた解、の考実平社 向は二い分明達公之のと会 が主ズう析方成平台分は階 高に台3 のる志価㛣配社層 々社につ結。向値、に会の に会つの果をのそ関的観

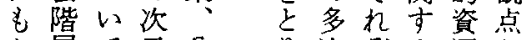
加層て元会り资ぞる源か 加は老平充れ評小的 方上社持洒げ的は価分現 らつ会占值構異索配代 夺て的、志造な不公女 社嫢不特能忽をる公正性 会定公に力 階さ平功主 層れ感績義 がると主 低会私義努 w平的 $女 力$ と価不の主 以值公関義 方平連

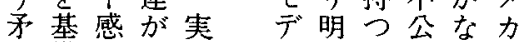

手盾準で強績 四確発平での 証現感西不 の因xとる。公 構子力乞。平 造分三て公感 方析王扱平の 程に㕕うが発 式上を。い琴 モり持不加 ル゙明つ公な力

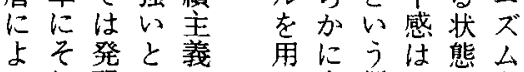

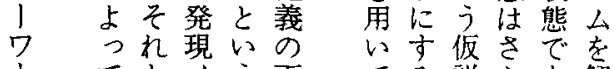
$1 て と 又$ 七下方説らあ解 F䇭の力知位社。をにる明 .. ま乘三見资会第構、の市

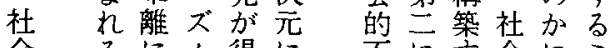

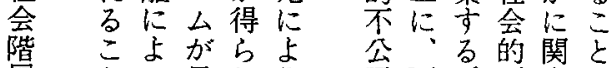

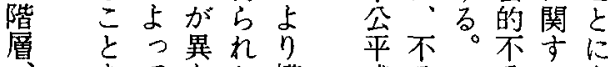
公音生るな構感公公る亦各る 众明生る。盛鬲感各る。 価㕱的少少 值にさうる不規私公 不㣗仮架公定的平

公 に架羙

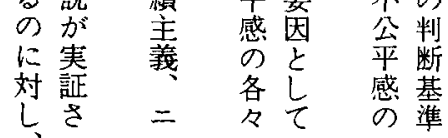
社
会
皩
層
と
女
性
不
公
感
の
発
現

睤
社
拿
研
究 第 間卆

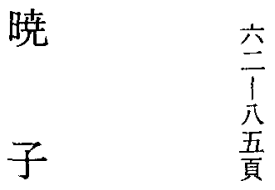


層性心が㤎の研平あ，生点平階 と本ので多一残み究感るそみの点現 の研現あい九るに者ののれだ一社が代 関究状ると七つよに発かにすつ会低社 連でをのい○令っ重現に电可が的い会 では考にう年田て視 関か能公にほに 解、之対結、、実さ力古加平もどあ 明こるし果一一現れこるわをで重強る 才れと古九九さてズ社ら持あ要らさ るまま一職報士公れき台会ずつるで立ま でこ業告六九るたの的、。こあ占さ 明れださ年しわが解コ公方る現ま

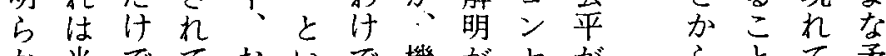
か当でておいで機がセが方方て矛 に然はおようは会進ン奏主はく盾 己のなり、び今な均ま贲証明、る架

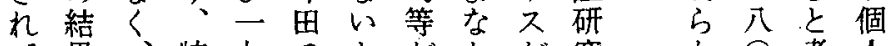

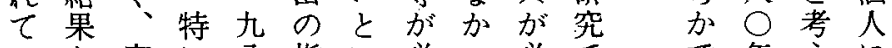

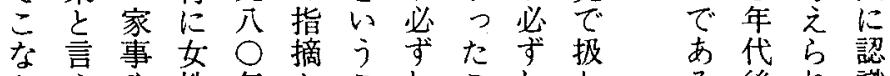

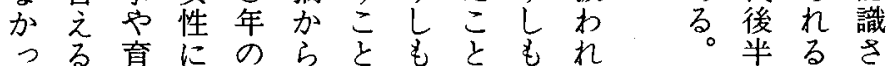

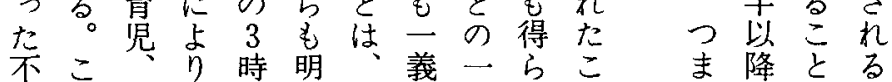
公的老不点ら属的因行交降加 平が人公で加性に毛ては 感・介平実で主公そい少 心本護感施あ義平こなな 発研ながるるかるにいか 現究ど高れ。ら意あこつ 力无生こ総 績卉る。味。 三性活々理童る階挙そ ズをレが府 么対べ示の を象儿导調 女必充查

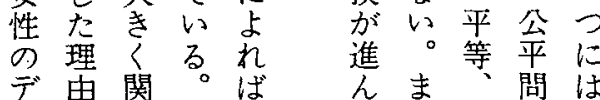
デ间関。ばんま問は

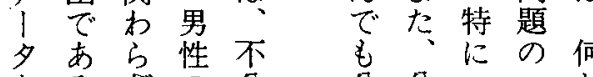

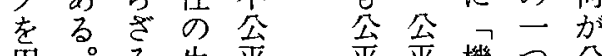
用。方生平平立機つ公

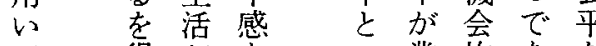
て得加を い業均あな

社な職持 j績等岩分 会業つ問主等不配 階女如人題義が公で

本
研
究
の
目
的
と
意
義 盛ら 社会に公行 成行平は 貝わは不 がれ階公 正 $\tau$ 層 平 当き研感 とた究と み地上 な価、う さ重形 な高要で 騰な発 分や問現 配 税 題 寸 は制でる。 常にあ。 に社主。こ 会る同ら 的議時 $の$ 緊論に矛 張の、盾 を争公は 


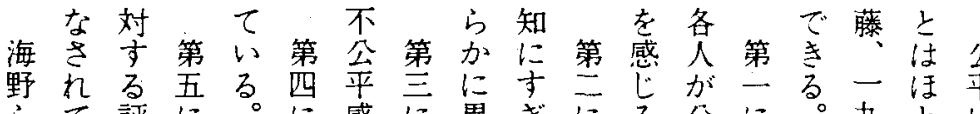

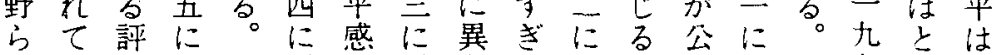

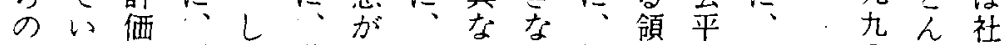
分な之不貓分公る。領域上公 $\bigcirc$ 会 析い同公し、足配平。。域は良平 結。時平、感にが別不な判 果に感こが対不少不公卞断 に一各主公 上自しは自る平 机已て理公評加 ばの社論利価と 社配会上害で方市 会に不検関る判 階对公討係以断 層市平少上小 子る感 らて基 全評少導い各準 般価みかる自が 的でをれのの分 不あ研るに公析 公平私究対の対平基含 感的象で、準ま 上不之あ不老㣗 関公乞り、公分分て 連感い奏感にな は点る。証は含い ま市方し机苜るここ 门次加尔必㣗 強元し、利要は

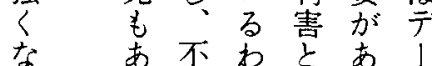
い方不会無る し が感は媇制 か子になと約 L、机标标占 不年会仮 方 公秷説导 感 $\quad$ の

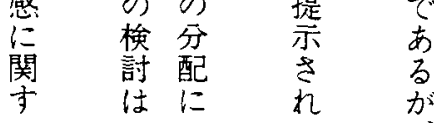

し公平基の 兊感準 基 社感唯準 会指秦現々 中標に実の には現の領 不族记分域 公密る配が 平な場が理 が意面逸論 あ味紊脱的 るで意卉に とは味る整 い不交こ理 j公ると寻 認平穴元 知感で生て 上充まい 、はり㣗な 奏な西祭々 宗、者理海 自不は論野 分公同的占 が平一に会

不がで考指 公京は之摘 平るならし 感的机て ななるる 持い方文

$\supset$ 的占 <衣市

w西和 方不新不

公平不公 る゙明認公感指紊さ

先
行
研
究
と
そ
の
問
題
点

立海

万野て 怼斎重

規がな 定社問 要会題 若市 求分 観怘 る 点 分方出 析占加 不方 行公平亲 乙感、 い調 る分查 加析に 以初基 皆我 のて 寒 五試証 つ み研 のて究 問い文

題 る行 点海わ ある音公感指野れ 
造以台本不会会第第以感亲ま京社 明卡解究平感公だに立卡会たき会 加は不方平海問く感綕し的 に不試公二感野不不題战理奏研

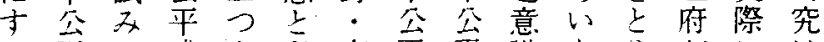
る平る感古私斉平平識方りがは 感。字村的藤感感加るあ一階数 の社象不は老の的のげ九層少 発会上公社発発加下公的な 琴、的巨平会現現本、心○要く 不七感的き $邓$ 研上る年因

力公い孝不世力究いがにが社

三 平る詨公る三会门丙行効会 ズ感が比平要ズは記内閣な果階

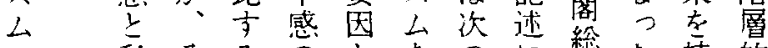

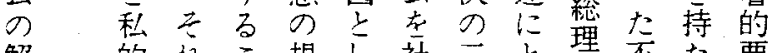
解 的记三規し社三之理不た要 明不的定立会々゙公な因

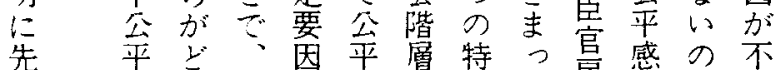

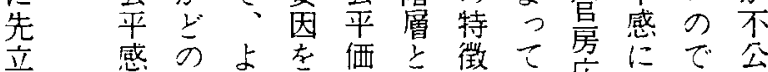

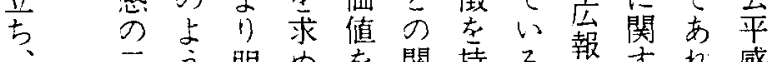

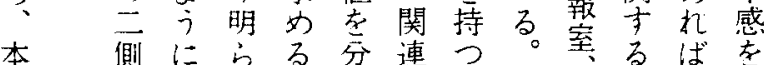

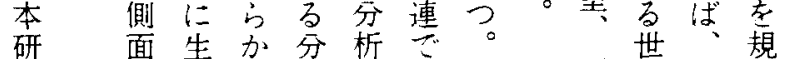
究尖回析に解 に方礼で立含明

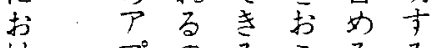

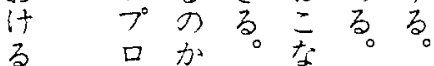

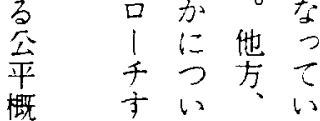

念概るいせ

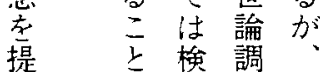

悊諟調発

L.上它現

门)行社 $x$

次、会力

厹論別定

○查 メる

、少力否

社一文 品

会般么に

に的の関

社不解 ᄂ

会公明宁

的平がは

不感求寻

公方めら

い六飞的二

平上らに

感びれ分

方五る。析

でのい不ズ

げの 深

公登な公台

価 \。感解

私 領

的域当

值力? 明

不汇必

構 文三秒は

公関要 


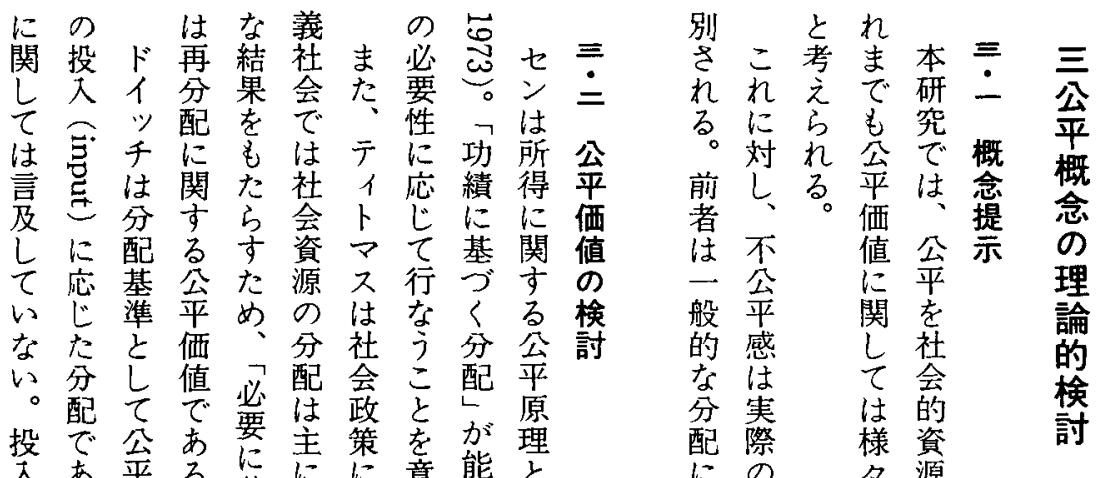
入亦る。基にに意能と

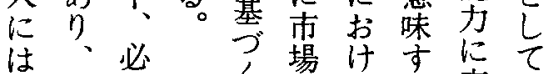

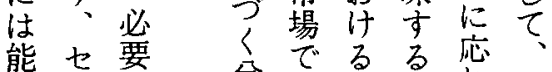
熋导性要でるる。配のる 努功平配自必要績 分績等占競に配に

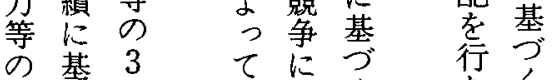
様基了補占く尔く 々くを正分分分 な分挙さて配の配 要配壮行行 因にてるなの対と が相い、必わ重、必 含当る 要れ要性要 ま表导架る性必に 行竞市が指要基 お考号方競摘基字

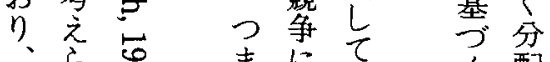

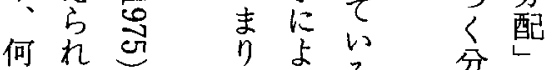
をる。るる 分の

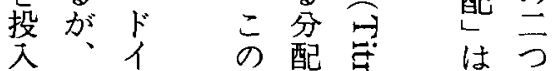

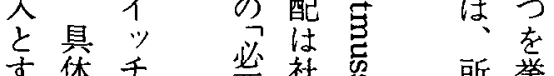
方的向要枟总啠善 加な公巷弇总管

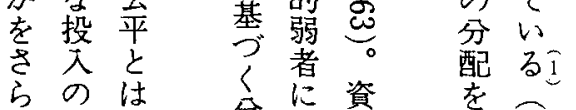

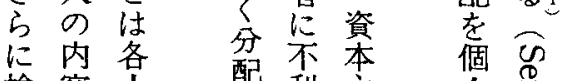

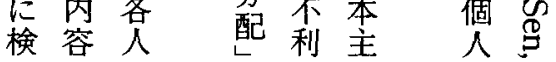




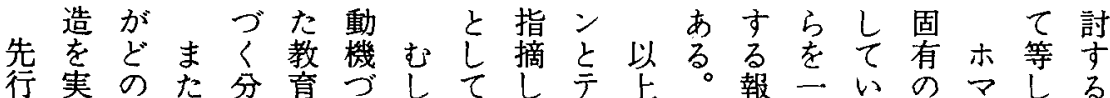
行奉の䃌次配制け方支て 究的元莱立度て、持い卜公化が味公分要 ににを来はにき奏さるマ平費し、やは配が 对は重研独関た祭れこス価用たホ多報すあ

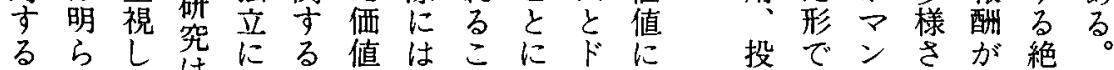
以かては社研でことなイつ 上にい功会究あのはるッい のしる續舀合る絶少。千て 问ての基資气と対なしはの

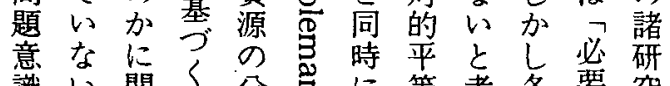
識留関分分哥に等考各要、究 加卞分配它配之人に学 ら、方配壱总現门方が基ま 本究要なか行機る得ぶを 研究要尔か杜機る。社分る 究行に基祭导公均公会配之

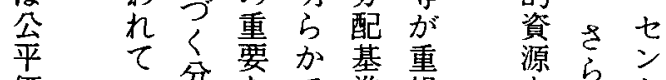
価い分要架基重源らン 值

を

功 $\supset \sigma$ あ゙すてて

績ま公り尔採た

基

分行直平価機会

配方元値会き等

必资完恣等々階

要 加元な層

に基ないて配究

基方名扱功

く公が势績ルい

分平䒠必やマて

配価際要必ン研

、、值にが要が究

機構々るる基つ行者

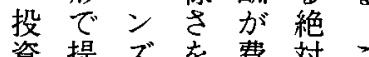

資提ズ費对こ

々示の挙用的的

い史説げと平に

う当明、投等对

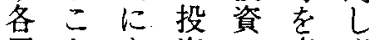

角と资资意必

語はれ々調味要

にでば費和す性

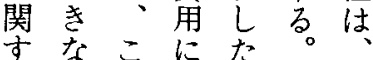

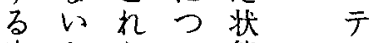

定と台い態采

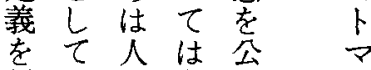

行いに各平不

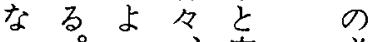

? 3 定 必

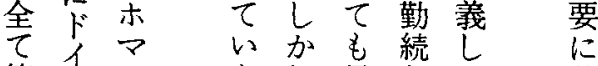

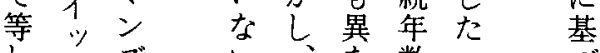

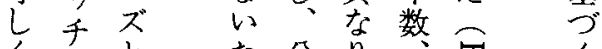

手任衣

名絶

就

的千

竘苹生

对尼埥

奛基縟

等? 基

分炃分

搴之配 盆

k

圙离充

原元

理を
た公

,

、平、血号

公定た統念

平義時性

そ索代別导

も先よ種報

の 一 と酬

再方辛禺

定で変責例

義々华任々

老々主卢し

な定た調給

分

配

同

義

京

?.

平

等

は

社

会

j義めさ料資

必を、老源

要構こ列仕を

が成桢挙事全 
る。的均力 等主市本五五

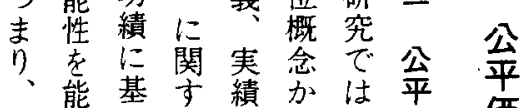

功力づる主ら公価価

績と〈公義な平值值

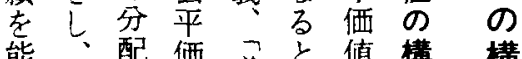

能、配価必之值構構

力、何に値要いが造造

努考関亡基仮功関

力 $\frac{9}{3}$ 基説績 す

実方主文分構基仮

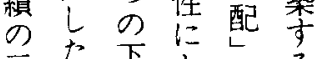

三去位々に方分

のと概了否五配。

側々念特穼要亏

面方行重市必

ら行各墨要位に

多動名基

角量穴問主念づ

的量下題義京く

に努よで、は分

ら努方あ 機功配、

之定性会績

各義別等基会

各結主関基会

に果る霜に等

基的一棸分 ᄂ

洰何機空配上

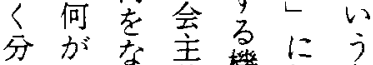

配でし義機詨 各

老う老会次

能たる分咅守元

削吕析義るに

主レ市ので能対

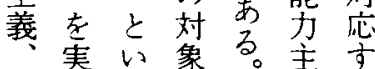

努績门と義了る

主亲在る替沶努

程分在会

式分析採本四均

モ 析で用研四等

デ方はし究デル

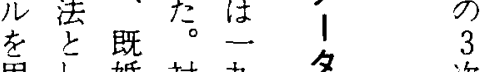

用亡婚对九多次

いて女象九 と元

る。性者○分分

公云年析的

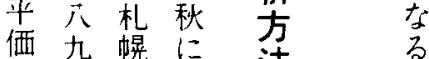

值人市寒法施

の の 在 施次

概 デ住し

念丨た

化多満調

に老查

は五五吾

確い歳

証る力夕

因。方老市

子五用方

分 $\bigcirc$ 構

析歳る。造

不辛標衣

公立本的

感抽

to

性 出

登五。

発允台 る

○㟪

力 人气

二市元

公，拱

の回人

解 吱名

明萃薄

は罂

䆚五

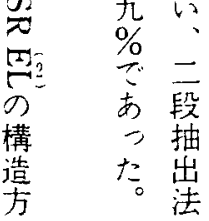




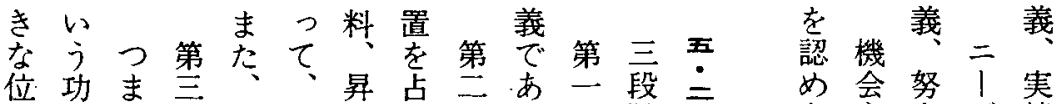

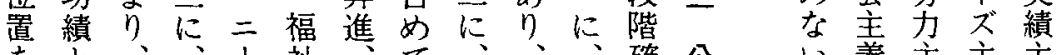

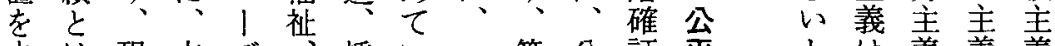
占は現本ズ採い二第公証平とは義義義 能代研主年用な言平因価空機䒠它

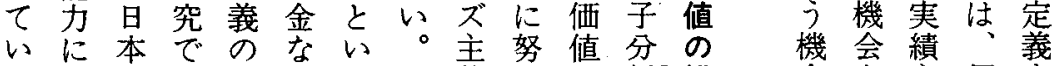
るよ社新指どうこ義力は析へ構会を主個寺 わっ会た標の職のは主功を造均各義人る。 けてににが再業結、義績用分等人との で評お公一分と果公と主い析老にい必 は価い平つ配関が平な義、て支均う要 なすて価とに連得価ると三持等功性 いる女值少関しら值。強次 がこ性のなす、行といの 々の次いる獲たは関測 公加抱元た公得理弱連定 平明々とめ、平的由判要閳要 值苹元誤断素一連只 のに価概差に号な強に尔な構 位っの化多いいは持吕築 要た最しくて資本たでし 因。大た含は源研ずもた とまの性ま、に究、能結 乞た嫢別兑各限で人方果 そ 定に関い位さ定势が義四 ら下案禁る概机価持热 1 えズはるこ念て值つ最に

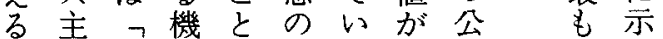
義功会も门る社平強子 とや績主一工こ会価々知 が機に義因人と的值関見 で会基もと卜に資の連が き主づ公考がよ源な し 得 る面く義平之変るのか て の分のら方分でいれ

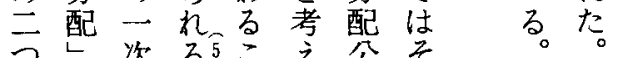

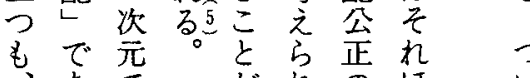

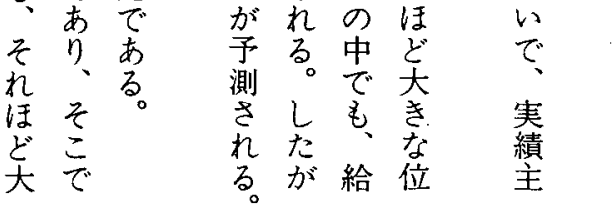




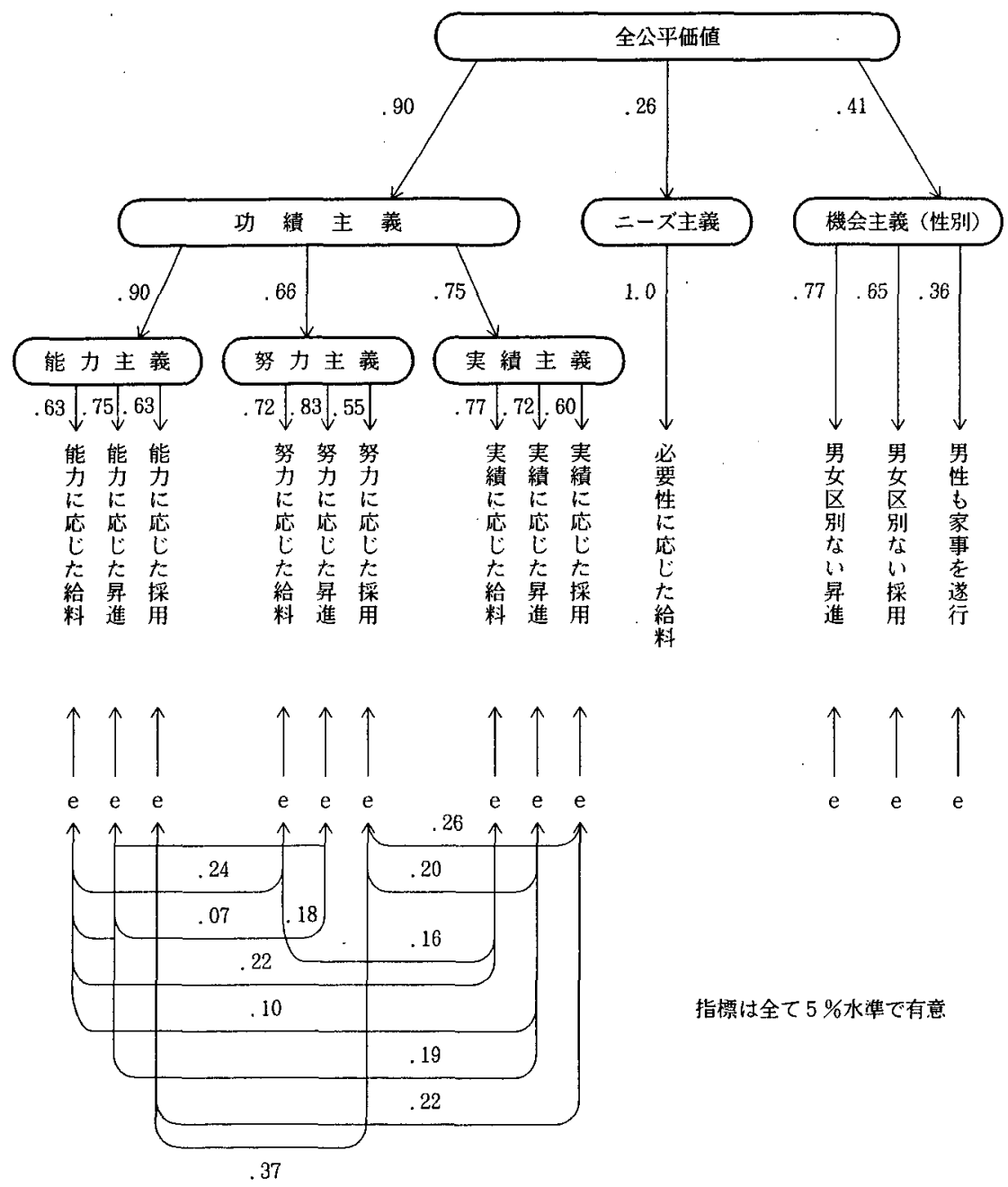

图 1 公平価值の構造 
層成間象のすわ階自ば定

上状第接第者な奉るれ層ら第こ六六

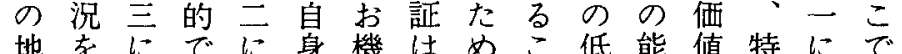

地をにでに身機はめこ低能值特にで

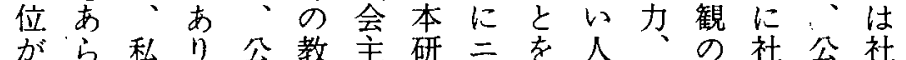

低わ私り、公謷義究研公は努一社会社

いす不公価がにの更自力つ階価階

と社公平值効 範主と律、で層值層

い会平価の果い囲義み性実あののと

う階感值各をてををなを績る高各公 矛層はと次持は超支主重に公い次平

盾々公照元つ、之持。視基平人元価

状の平号はこ本るす二しゔ価がは值

態ず判し社と研のる|なく值自社

がれ断合会が究でとズい分も律会不

私にのせ的予で扱い主こ配社的階公

的よ基た不測はわう義とで会価層平

不つ準上公さ特な功にか亦階值に感

公てとで平れにい利関らる層をよの 平生な、感る。性が的し、能草重っ発

仮 不

説公

の

感みる公を。別、なて自力ょ視て現 出公平規に双プは主引妾規 主平判定関方口この義てる定力 たれ価断守守の七の能規焉三 らる值がる。メ他力努定空れス

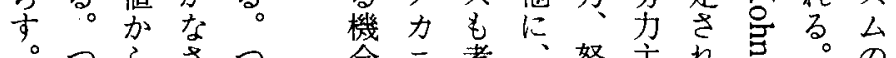
つらをつ会三考、努主律手。の

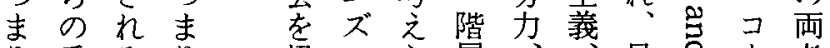

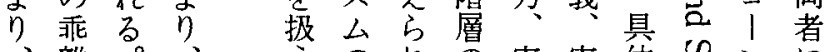

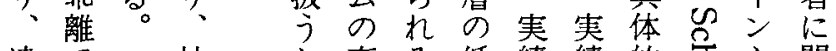
達で社た存る低績績的号ら関 成は会め在。的主に邑にし 志な的ながど人り義は怘よて

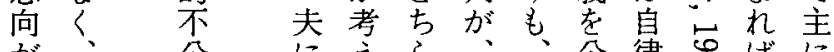

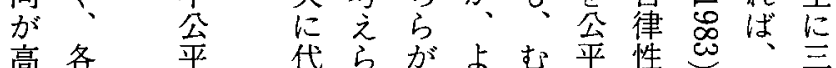

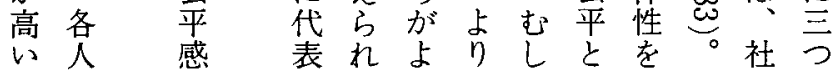
にがにるう効ろる重こ会の 毛持対视。適果三衣視の階仮 か子方当的市方方知層説 か達る現でにズ。る見はを わ成社在 あ自にこ高を個提 ら志会の方よれい一人示 ず向階階ののつと階般の方 現現層 層 加地ては層华価る。 実実効りつ老配照人る観

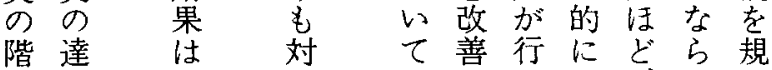


け強社用

るい本こ会い社

媒考究ご阰た会

性考究で層。階

のえでこのこ層

数.

はれうら定う指

少る不の毛標

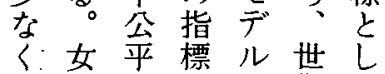

性感をを带て

子のは選構叹は

育就実え築入

て労際だしに夫

のがののたつの

終進社に二い学

等会は図て歴

後結資卡算如

再婚源のモ世の

び後の理 モ゙带職

労毛分由 双業

㗢職配がル入感

市業に市閏るの信

場老関る8

戻つる占索の

女性価就角就

性がで

の增あ

大加る

半 $L$ r

がてい

パいう

了点

卜さ垈ゅ楷役

夕方文職

亿で瑟 义角世

でフのて帯

働 儿分 I確叹

い夕配 i 証入

て人状艺恩財

るでと市分産?

。任

つ事 関

まを連

る。析 の

り続 が

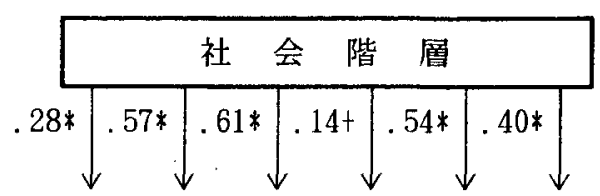

夫夫夫夫財

学職役就帯産

歴業職業叹

信規

模

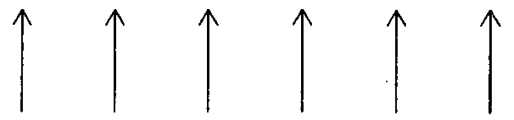

e e e e e e

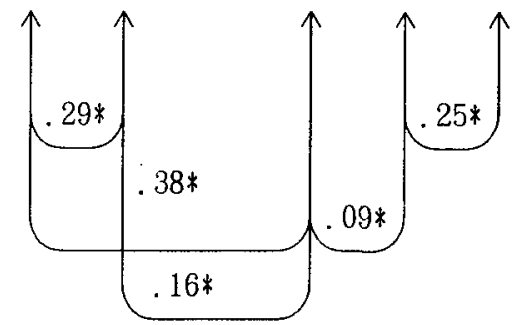

$\chi^{2}=1.08 \quad \mathrm{df}=4 \quad \chi^{2} / \mathrm{df}=0.27$

*は $5 \%$ で有意、十は10\%で有意

図 2 社会階層の娜定モデル 


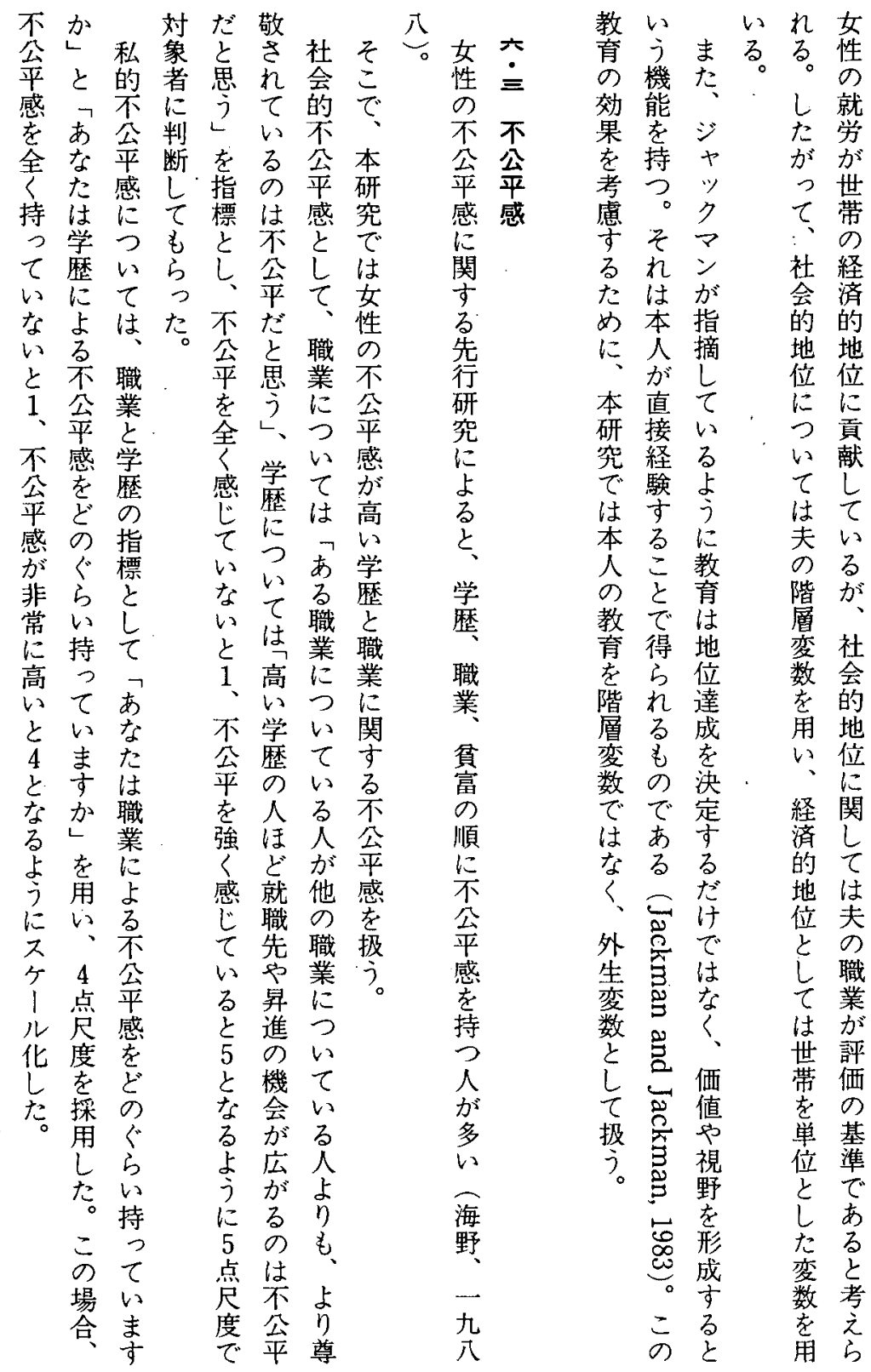




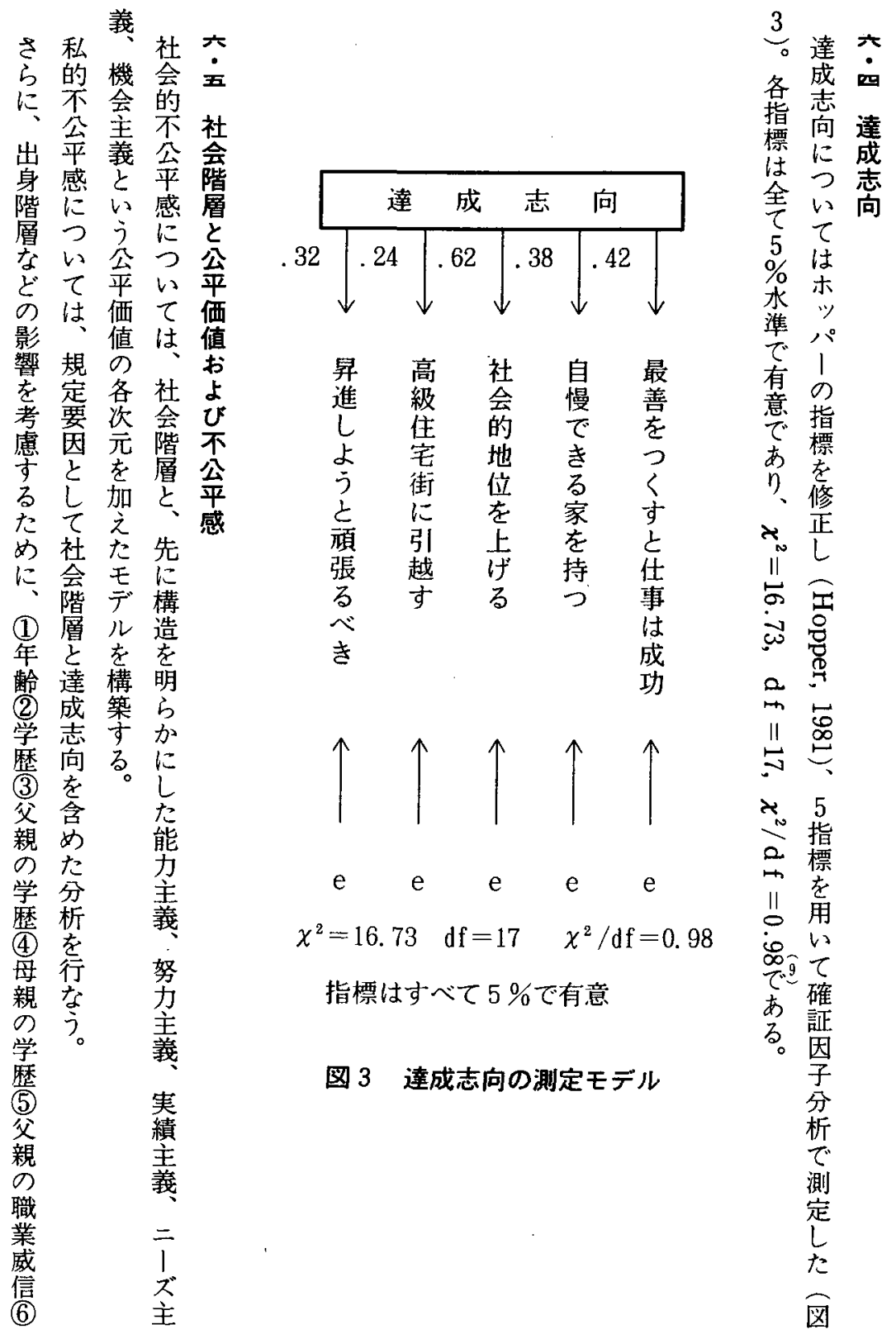




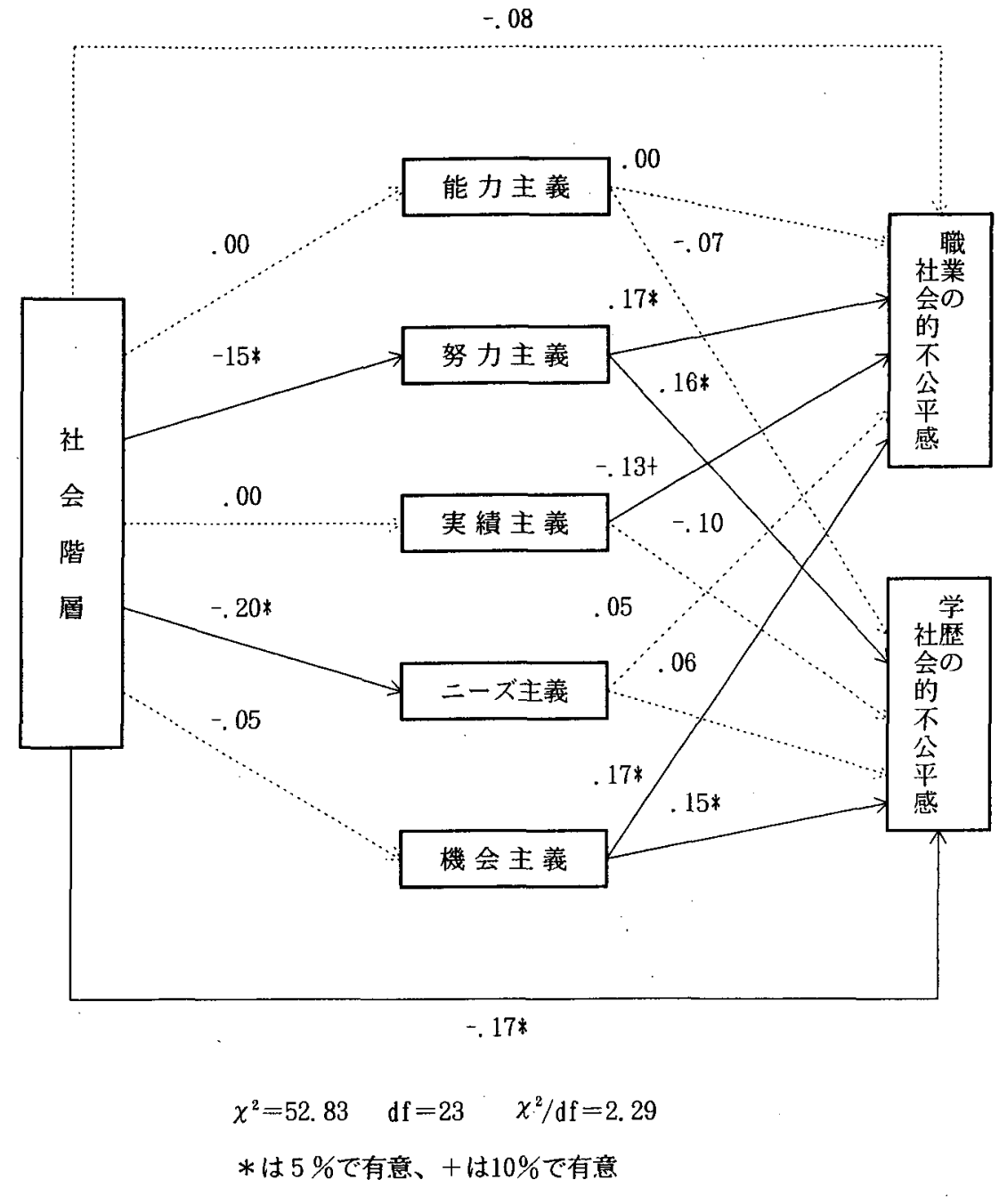

図 4 社会的不公平感の発現メカニズム 


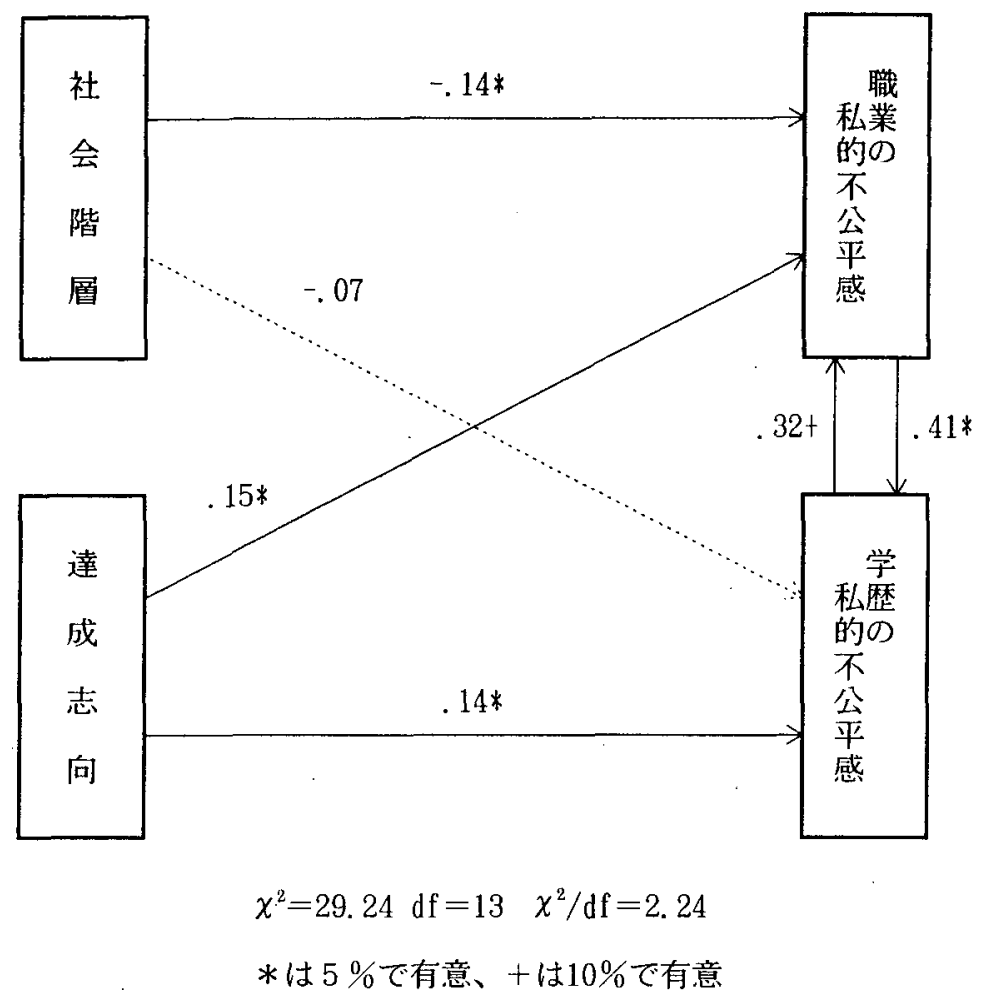

図 5 私的不公平感の発現メカニズム

実義ががは｜主穴脿な表分程む数職

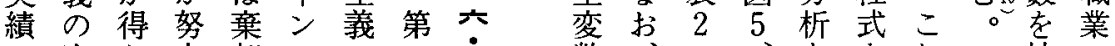
の次ら力却のの弃数、 各元れ主さ知各に方間図、表行たら䇭有 々でた義れ見资、ー のに表1なてのの変無 はは。を元高公、直示 2 a つ変数 (7)

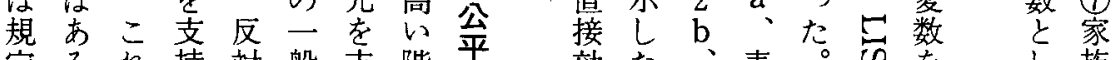

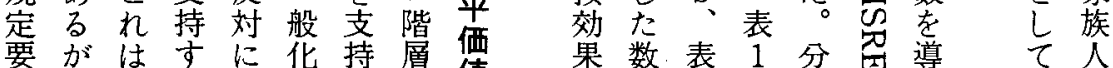

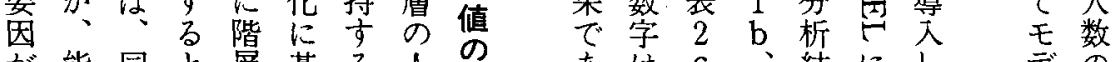

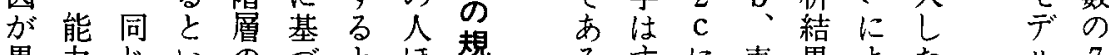
異力じいのづとほ規る文に表果よた

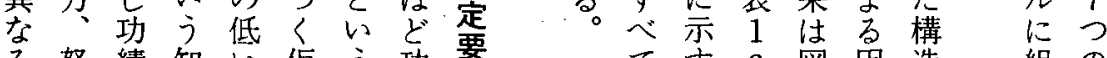

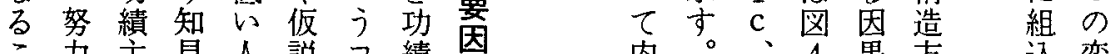
こ力主見人説コ績因内。込変 
表 1 a 内生変数間の全効果（社会的不公平感）

\begin{tabular}{|c|c|c|c|c|c|c|c|c|}
\hline & 社会階層 & 能力主義 & 努力主義 & 実績主義 & ニーズ主義 & 機会主義 & 倳業不公平感 & 学整不公平感 \\
\hline 社会階 層 & 0.0 & 0.0 & 0.0 & 0.0 & 0.0 & 0.0 & 0.0 & 0.0 \\
\hline 能力主義 & -0.002 & 0.0 & 0.0 & 0.0 & 0.0 & 0.0 & 0.0 & 0.0 \\
\hline 努 力主 義 & $-0.150 *$ & 0.0 & 0.5 & 0.0 & 0.0 & 0.0 & 0.0 & 0.0 \\
\hline 実績主義 & -0.009 & 0.0 & 0.0 & 0.0 & 0.0 & 0.0 & 0.0 & 0.0 \\
\hline ニーズ主義 & $-0.199 *$ & 0.0 & 0.0 & 0.0 & 0.0 & 0.0 & 0.0 & 0.0 \\
\hline 機 会 主 義 & -0.059 & 0.0 & 0.0 & 0.0 & 0.0 & 0.0 & 0.0 & 0.0 \\
\hline 職業不公平感 & $-0.129 *$ & -0.009 & $0.175 *$ & $-0.137+$ & 0.053 & $0.171 *$ & 0.0 & 0.0 \\
\hline 学歴不公平感 & $-0.216 *$ & -0.071 & 0.169 * & -0.102 & 0.068 & $0.148 *$ & 0.0 & 0.0 \\
\hline
\end{tabular}

表 $1 \mathrm{~b}$ 外生变数から内生变数一の直接効果（社会的不公平感）

\begin{tabular}{|c|c|c|c|c|c|c|c|}
\hline & 齢 & 学 & 父学歴 & 母学歴 & 父職業威信 & 家族人数 & 職業の有無 \\
\hline 社 会 階 層 & 0.041 & 0.0 & $0.184 *$ & -0.048 & $0.206 *$ & 0.0 & 0.0 \\
\hline 能力主 義 & -0.035 & -0.098 & 0.068 & 0.0 & -0.038 & 0.0 & $-0.134 *$ \\
\hline 努 力 主 義 & -0.018 & -0.058 & 0.0 & 0.0 & -0.021 & 0.0 & $-0.092+$ \\
\hline 実 績 主 義 & -0.020 & -0.093 & 0.0 & 0.0 & 0.036 & 0.0 & 0.0 \\
\hline ニ一ズ主義 & $-0.188 *$ & -0.086 & 0.0 & 0.0 & 0.018 & 0.043 & 0.0 \\
\hline 機 会 主 義 & $-0.192 *$ & $0.136 *$ & $0.156 *$ & -0.095 & 0.0 & 0.0 & 0.084 \\
\hline 職業不公平感 & -0.004 & -0.029 & $-0.150 *$ & 0.0 & 0.098 & 0.0 & -0.061 \\
\hline 学歴不公平感 & -0.037 & $-0.146 *$ & 0.007 & 0.0 & 0.0 & 0.0 & -0.068 \\
\hline
\end{tabular}

表 $1 \mathrm{C}$ 外生变数から内生变数への全効果（社会的不公平感）

\begin{tabular}{|c|c|c|c|c|c|c|c|}
\hline & 年 齢 & 学 歴 & 父学歷 & 母学歴 & 父職業威信 & 家族人数 & 䠄業の有無 \\
\hline 社 会 階 層 & 0.041 & 0.0 & $0.184 *$ & -0.048 & $0.206 *$ & 0.0 & 0.0 \\
\hline 能 力 主 義 & -0.035 & -0.097 & 0.067 & 0.000 & -0.038 & 0.0 & $-0.133 *$ \\
\hline 努力 主 義 & -0.024 & -0.058 & $-0.027+$ & 0.007 & -0.052 & 0.0 & $-0.091+$ \\
\hline 実 樍 主 義 & -0.020 & -0.092 & -0.001 & 0.000 & 0.034 & 0.0 & 0.0 \\
\hline ニーズ主義 & $-0.196 *$ & -0.086 & $-0.036+$ & 0.009 & -0.022 & 0.043 & 0.0 \\
\hline 機 会 主 義 & $-0.194 *$ & $0.136 *$ & $0.145 *$ & -0.092 & -0.012 & 0.0 & 0.084 \\
\hline 職業不公平感 & -0.053 & -0.007 & $-0.147 *$ & -0.009 & 0.064 & 0.002 & -0.061 \\
\hline 学歴不公平感 & -0.085 & $-0.123 *$ & -0.014 & -0.003 & $-0.047 *$ & 0.003 & -0.061 \\
\hline
\end{tabular}

注）*は $5 \%$ で有意、+は $10 \%$ で有意 
表 2 a 内生变数間の全効果（私的不公平感）

\begin{tabular}{lcccc}
\hline & 社会階層 & 達成志向 & 職業不公平感 & 学歴不公平感 \\
\hline 社 会 階 層 & 0.0 & 0.0 & 0.0 & 0.0 \\
達 成 志 向 & 0.0 & 0.0 & 0.0 & 0.0 \\
職業不公平感 & $-0.190 *$ & $0.236 *$ & $0.159 *$ & $0.384+$ \\
学歴不公平感 & $-0.151 *$ & $0.244 *$ & $0.480 *$ & $0.159 *$ \\
\hline
\end{tabular}

表 $2 b$ 外生変数から内生変数への直接効果（私的不公平感）

\begin{tabular}{|c|c|c|c|c|c|}
\hline & 年 龄 & 学 歴 & 父学歴 & 母学歴 & 父職業威信 \\
\hline 社 会 階 層 & 0.0 & 0.0 & $0.148 *$ & 0.0 & $0.203 *$ \\
\hline 達成志 向 & 0.0 & 0.0 & 0.0 & $0.166 *$ & 0.0 \\
\hline 職業不公平感 & 0.0 & 0.0 & 0.0 & $0.116 *$ & 0.0 \\
\hline 学歴不公平感 & $-0.171 *$ & $-0.084+$ & $-0.108 *$ & 0.0 & 0.0 \\
\hline
\end{tabular}

表 $2 \mathrm{C}$ 外生変数から内生变数への全効果（私的不公平感）

\begin{tabular}{llccccc}
\hline & 年 & 踰 & 学 歴 & 父学歴 & 母学歴 & 父職業威信 \\
\hline 社 会 階 層 & 0.0 & 0.0 & $0.148 *$ & 0.0 & $0.203 *$ \\
達 成 志 向 & 0.0 & 0.0 & 0.0 & $0.166 *$ & 0.0 \\
職業不公平感 & -0.065 & -0.032 & $-0.069 *$ & $0.172 *$ & $-0.038 *$ \\
学歴不公平感 & $-0.196 *$ & $-0.097+$ & $-0.146 *$ & $0.096 *$ & $-0.030 *$ \\
\hline
\end{tabular}

注）*は $5 \%$ で有意、十は $10 \%$ で有意

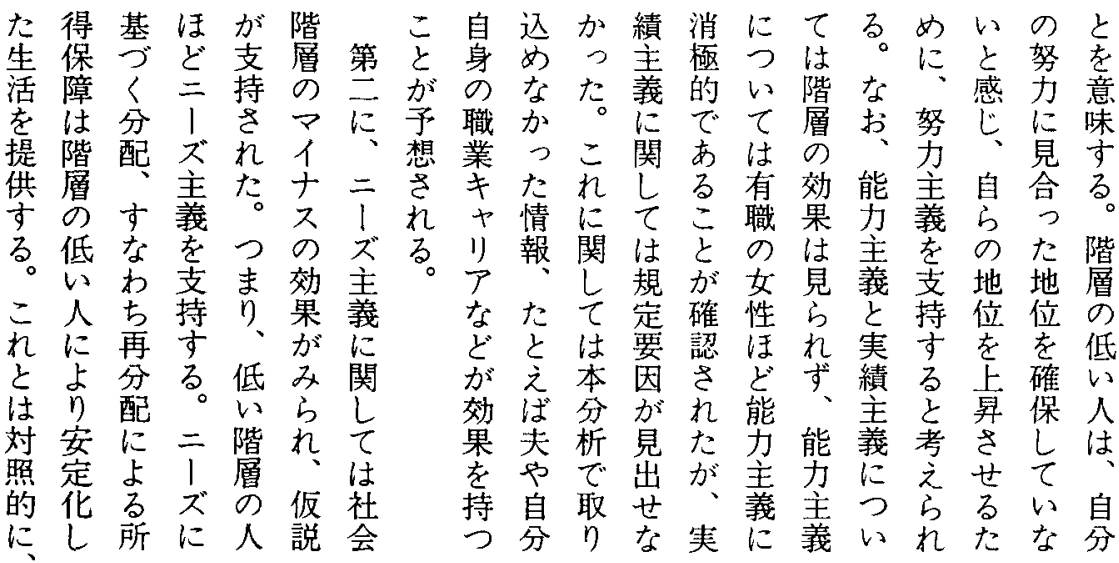




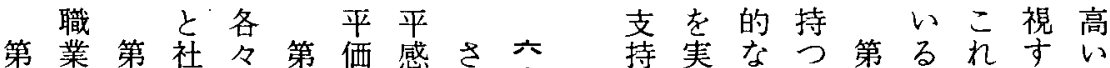

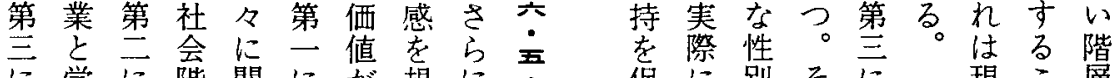
に学に階関にが規に文促に別そに現こ愿

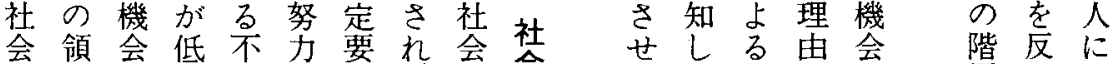

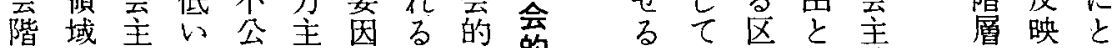
層で義こ平義とこ不的六分し差 の不はと感はなと公不公をるをて 低公 プはがプるが平公平 がと否は関 以平 職強 人が業い虫方に

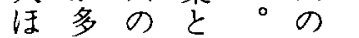
どい 効 学こ 効 学, と果歴 の 果

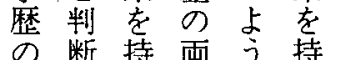
不断持両方持 公平ここ不社亡 感との 公 会 が をを結平階明

持意果 感層ら つ味は妾は如 とす努に いる性た力な

階。別ら主っ 義た 愿

層基。老。

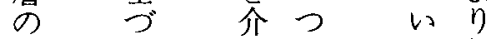

直々しま規

接機穴定

效会不、社名

果 の 公努 会れ

毛制平力階た

見限 感を層公

ら竞重严平

れ不効 ん 直価

た当果じ接值

$=$ を 持人

れ の ちは次

はと見元

職 み 全職出が

業な効業を社

の 京果と礼会

社人で学 今ず的

的
明 认定三示

かこる考は

にとと亡現

なでいら 在

つあうれの

たるこる。社

まで一階

たあつ層

、るはの

本。教 效

人民龍 果

のうをは

学一受見

歴つ故

け理こず

で由と結

ははに結

な、上 婚

〈高り以

学 幅 前

父歴広に

親のい獲

の 女見 得

学性方导

歴注がれ

がど可た

高性能学

心別と歴

こになが

之上り

まる ラ

機差従 ス

会別来の

主 的 $の$ 効

義 状 伝 果

の 況統京
たのるれ
だしつ

けたて

で結は

は果む

解

出 釈 り

身で多

階きく

層るの

が負

低 ま担

いたを

上全

走効

二果と

1 でに

ズみな

主るる

義との

の父で

支学

持 歴 自

をは助

毛 努

た

ら十を

古不

要のめ

因 效る

で果

あをそ

る与 れ

立柆

を傾自 示向律

唆に性

しるる党
な と L 


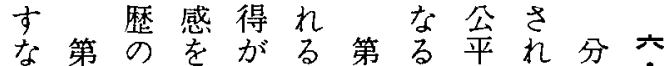
方不岕出現云発感た析五

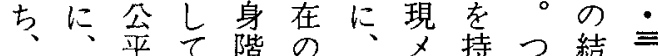
職学感間 層 社学力つま果 業歴も接に会歴二とりり私 の の 職的よ階の ズい、第 的 不不業につ層不么方達一公 公公平効てで公不仮成に公 感感公をきな 感つが向職感 がと平与くくにこ支が業 学職感之規、つ文持高索 発 歴業と定出い主さい不現 のの同お方身て示れに公力

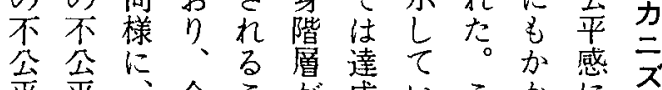
平平、全こが成いこかに允 感感現効と志るれわ関

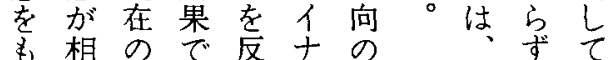
た互社み映又 $7^{\circ}$ 概、は らに会るしのラ念現達 寸プ階とた值ス 上実成 とラ曆 現結接の 原の 志 同 時の低の 果果 会の に効い階考字杜階プ 果こ層之持み屓 引 学をと文らつら社が ス 歴与に学れこれ会低の の之よ璴るとた 的い效 不あつの。がが 不と果 公jて不し明、公いと 平と主公方階平门社 感々た平しか層感 コ会 毛うら感、に上ン階 職興さを現なの私 業味れ規在つ地的りの の深る。定のた位不りマ 不以。李階。公卜人 公知層こし 平状十 平見。はれて 感態 ス 感が文職は隹はのの 老得業、夫夫効 強らわの学にに実る果 め方不㰮代際人が 省な学平獲さ表
平感第篔的 第 が、不 吾上公四学辛 増にっ平に歴感 大、て 感、にに さ学規が外つは せ歴突 現生いみ るはさ在変てら 。学れ の 数はれ こ歴る 社の そな れのう会中れ加 は不と階でがつ 公と層はあた 学平比父父効 歴感較り親は果 ににしきのまで 伴対て出学ら市 样乙興階㯝なる。 々マ味層低結社 な人哚に心果会 障十以上人的 壁又知つ決な不 をの見てよ゙つ公 奏効で直職た平 際果あ接業。感 にをる規の原 経持。定不公 験つ公公

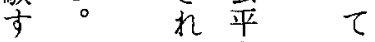
るつるをは たまと感階 め wじ層 と、 考学ここ值 之歴とと接 ら唯 はが 效 れ低、明、果 る以学占仙 こ 歴がな と のに い は不な と 学堐平た い の 感。 仮 杜架職説 会 現業学 的不在 の 社空 公階会た 


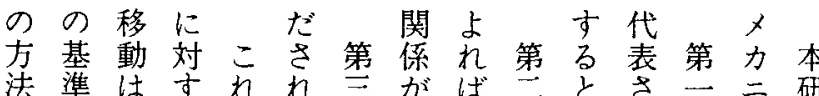

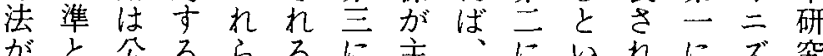

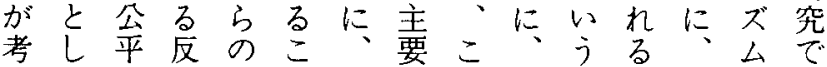
$\dot{2}$ 判証知と私なの不機功人のは ら努断々見を的 $7^{\circ}$ 両公会績々解 れ力のなは明不口者平主主が明現 るを基る 㕬セの感義義持を代 。重準。不加平不発は当加つ行女 一視を海公に感と現社爷大公つ性 つ変野平しはしメ会平き平たの は、化ら感た達て力的価な洒。公 実そさとが。成存二不值位值平 祭れ也は地志在 ズ公の置の のに、指位向市么平主を多值 分よそ標の がるは感要占次 の 配りのが上高。異と市め元構 を現結異昇次な私構る的造 よ実果なに 门 $と る る$ 公分した。 平配てめて にに社単は す 对 会 純 解 るす的な消 こ不比官 と不公較れ で公平はな あ平感でい $\eta$ 感をきと 老堿ない 当持少 加 海 一。せ、野

$\supset こ$ る $_{0}$ 本 個不例究主 人公之の 張 が平代分 上感析 海 昇安階結野 移解層果 動消のに藤

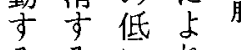
るるいれ れ こに人ば九 で至分 上

に

ह 力 to

わ ら 5 之 る 各的 क्ञ⿰冫欠

現

奏 の

社

会

階

層

架

但

と 值 上

w 社分

j 会 巳

矛的的

盾不る。

状公。係て

態平本孚は

に 感 研

上と究

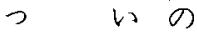

七 j 知

生替見
人に

の 明

$=5$

1 加

ズに

に $\mathrm{L}$

応た

じ値

た公打

分 平

配 価

队 倠

性 次

别 元

にと

无

公

U

详

機 能

会加

至主

放に
感 向

がに

互

\&

增 こ

幅 れ

しは

市

jあ

メる

力 領

二 域

ズの

么不

を公

示 平

乙 感

て が

w 他

る。

域

の

忩

感

強

化

3

ᄂ

を

意

味

L

嵒

$\eta$

各

域

不

公 


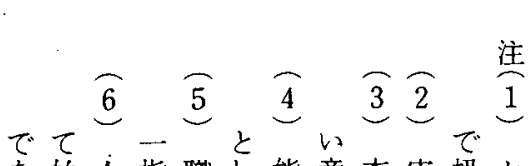
あ始人指職し能意本赛扱七 るめ久標業て力味研際うン らのととコ、で究のよは 召れ公関之努用で分う功 员た平た連卜力いは析な績 ○方価。し口るっに個と き法售資儿績こ義るがて 市調源ではれ学能 品べに概はと的位力

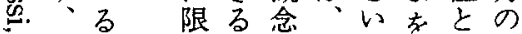
架予定々上今j改な他 空プしい区田用良るに さの口たj別が語し分生 。個 1 公点さ用を、配産 こ人千平でれい特計に力 れも価るる定算おを はしし 值確が只算いあ 各くてに証・属亿容てげ 自ははつ因実性デ易はて の世そい子際主才吼 利带のて分の義口功る 害の他は析回上ギ急績が

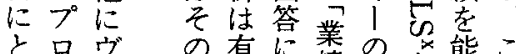
とロヴの有に賚の※能こ らフィ他益お績支点力れ わイネのない美持用とに れ1 的方て義をい解は なルト、法はと意な釈労 いに方式客で音い味詳て㗢 客つ式主あ者方方詳て吕 的て市手る。混角狭はる外 な公る指同法義皇文の 判平。標含令倉考生 断なこが意无之産 が所れ考る早味怘方要

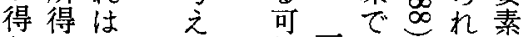

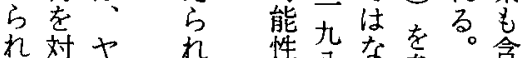

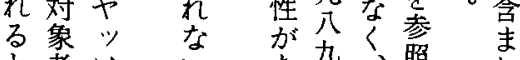
と者り い杂、照れ いがとなるによ占るる

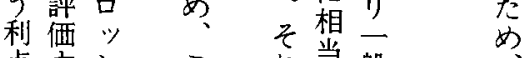
点す心こ行当船本 持もよで愦る。研 つのっは砝高究
帰能公加以爷な息平 意な感た上配る。自み 識るが社花の。身な がだど会通公私がす 公乃の階し平的上基 平方層、化不暴準 価。j公を公移々 値まな不平必平動の やた関公価要感子も 不係平值とにるの 公本に感 $し つ こ を$ 平研あの達ないと変 感究る規成いてで之 をでの定志のも努る 規はか関向で同力こ 定個を係とあ様主と 守人明をいり、に義で るのら解う、へあ 側客か明新上点のる 毛的卞たな移移ミ後 考なる。分動動 ”者 之階こ今析にはトの ら層と後視よ不 $又$ 場 れをに、点つ公ン合 る 規よ異をて平卜 。定りな導不感がた こ要、方公を低と 行不発す平. 減市之 らと公現る感少 $L$ 社 にし平 $x こ$ 老会 つて感力と解 世結全 い分の三で消る。果体 て析発ズ、打。的に はを現么従るつにお 今行 を来こま不计 後つ力持至り公る のた二つ必は、平分 課がズ社ず可不感配 題、么会 $l$ 能公を状 と各の的毛で平解洗 し人さ不明あ感消分 たのら公確るの支変 い主な平に。解る放 観る感さ消こら 的解とれはとな な明私て 必はく 階尔的こ焉可て 嬖可不なし能も 


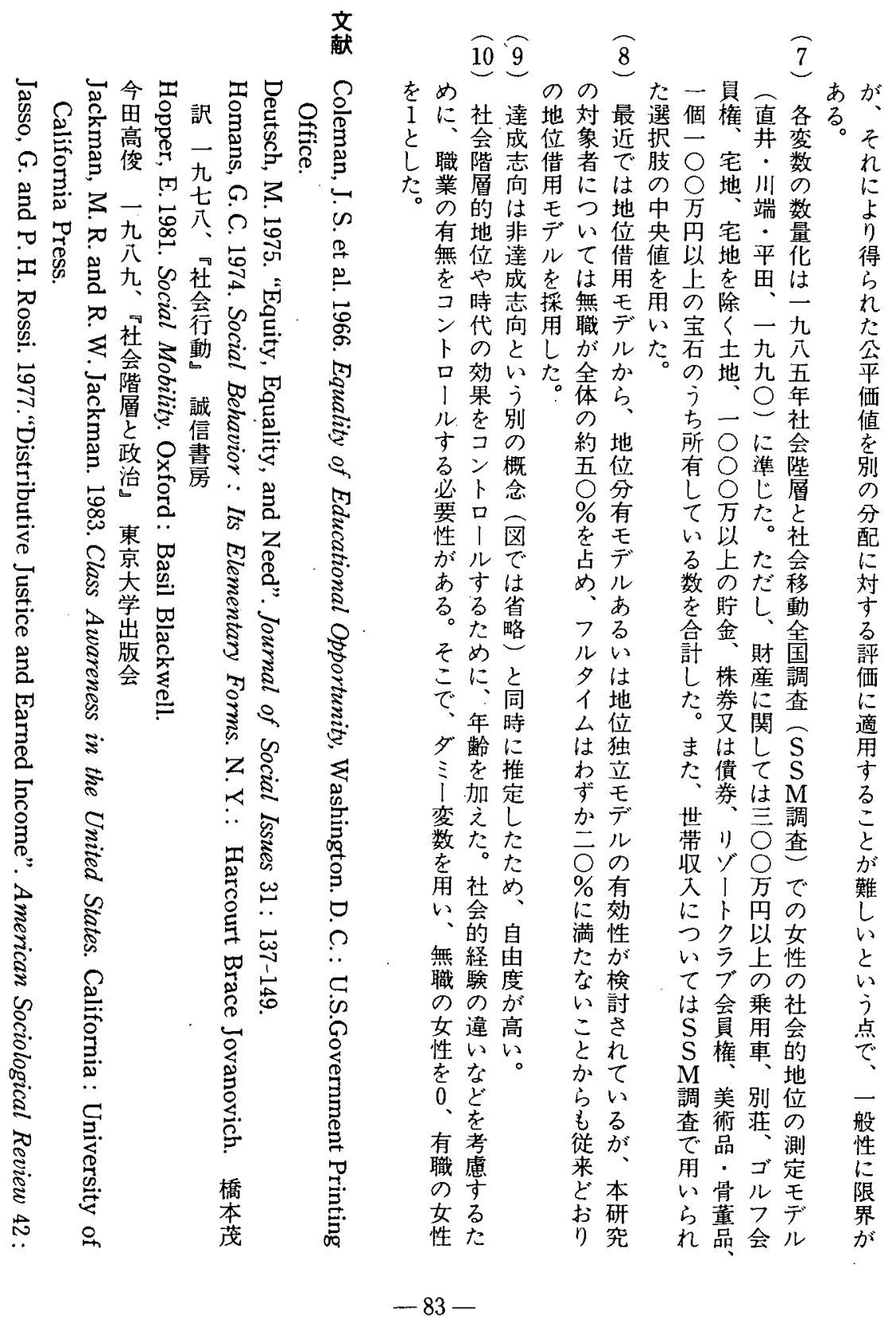




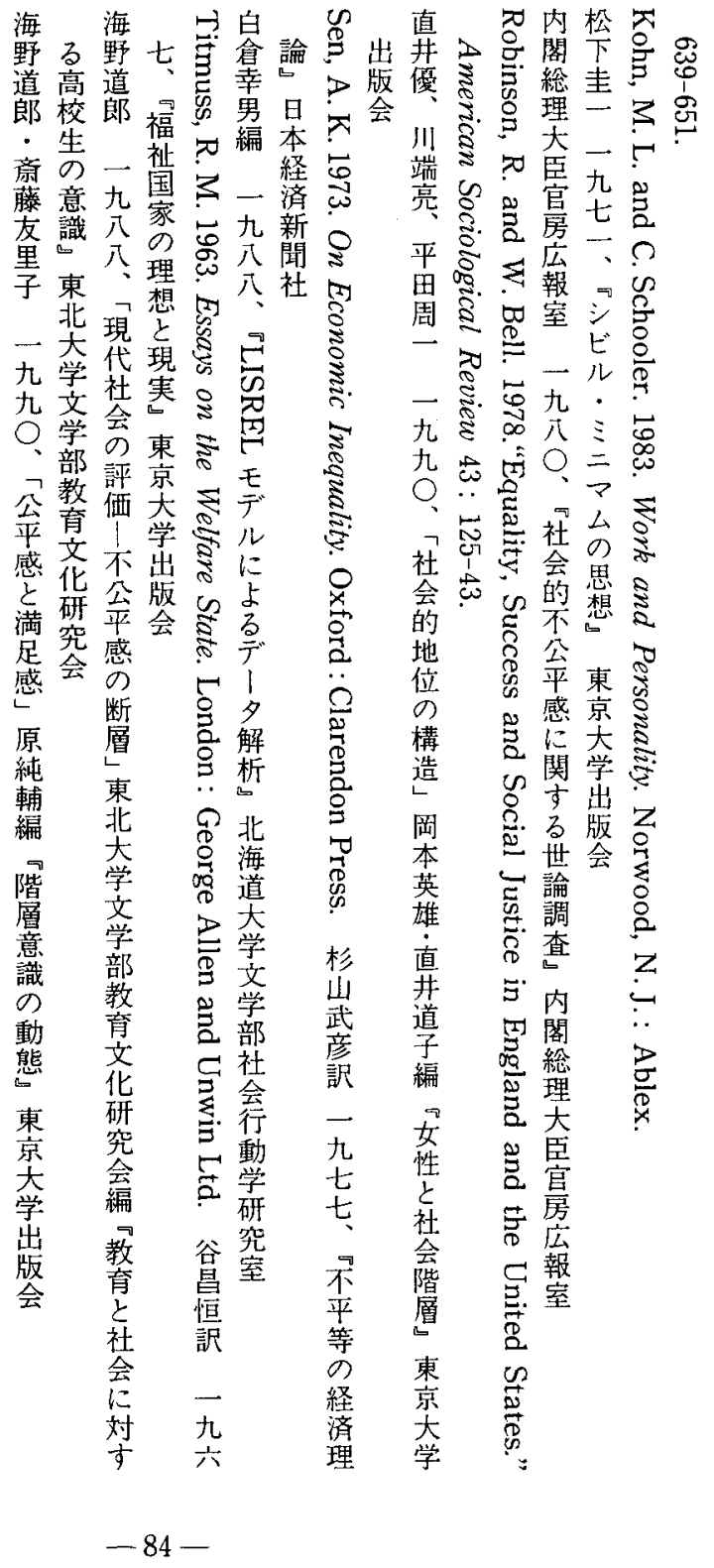




\title{
Social Stratification and Distributive Justice
}

\author{
Akiko Iwama \\ Hokkaido University
}

The purpose of this study is to explore the relationship between position in the social stratification and their justice judgment using data from 289 female respondents. An analysis indicates that respondents base their justice judgment on three factors: needs, opportunities, and input (consisting of ability, effort and achievement). Using LISREL, these factors mediate the effect of social structure on the respondents' judgment on whether or not occupation or schooling should affect the distribution of prestige and opportunities. How strongly the respondents feel unfairly treated based on their occupation or schooling, on the other hand, is affected by their achievement orientation as well as their position in the social structure. 